\title{
Factors That Influence Consumer Decisions in Purchasing Bakso in the City of Banda Aceh
}

\author{
Hanum Vine Meilliza; Suyanti; Agussabti \\ Faculty of Agriculture, Syiah Kuala University, Indonesia \\ http://dx.doi.org/10.18415/ijmmu.v6i4.1041
}

\begin{abstract}
The purpose of this study was to determine the factors that influence consumers in buying culinary called bakso (meatball) in the city of Banda Aceh. The results of this study explained that the characteristics of consumers who make decisions in purchasing bakso in Banda Aceh were female by $84 \%$, aged $31-40$ years by $52 \%$, married by $90 \%$, Strata 1 education level by $64 \%$, working as a housewife by $41 \%$, earning Rp. 1.000 .000 - Rp. 3.000 .000 per month by $35 \%$, and originated from Banda Aceh by $70 \%$. The results of this study explained that the factors that influence the decisions in purchasing bakso in Banda Aceh were external factors, namely price, product, location, promotion, and service, as well as internal factors namely motivation. Overall, these six factors are positive and altogether have a significant influence on purchasing decisions. However, partially, the significant effect on purchasing decisions is only three variables, namely price, service, and motivation.
\end{abstract}

Keywords: Consumer Decisions;Bakso; Banda Aceh

\section{Introduction}

Everything that humans consume as food or drink is called food. It has been a long time since the fulfillment of human needs for food ranked at the top of our life. Therefore, the problems related to food are included in primary needs or basic needs. For this reason, humans cannot replace their need for food because with food humans can continue their lives. Every food that human consumed must be able to fulfill nutrition, interesting to eat, has a delicious taste, and of course it must also be safe for consumption. As long as there is human life on this earth, the need for food will also always be there.

In enjoying the food we choose, everyone has their own way of fulfilling their desires. Some choose to buy from food stalls that have better taste and sell delicious food and according to our taste, but as a consequence, we must pay more expensive price. There are also people who choose to eat at a stall whose service is ordinary, the taste is also not delicious enough, but the price is cheap and in accordance with the ability to pay. Some others choose to go to food stalls that are truly in accordance with their wishes; provides delicious food, lower prices, and good and satisfying service. 
Culinary business has become a trend among the world community. The snack and food business is considered as the easiest business to run so that it has the most intense competition. The various types of snacks sold as culinary business resulting in every snack or food entrepreneur being required to determine a marketing strategy plan that would be used to encourage consumers to buy the food they sell.

In the book Essentials of Marketing written by McCarthy and Perreault (1996), stated that, the effort to find interesting opportunities and formulate marketing strategies that generate profits is called marketing strategy planning. This marketing strategy applies the target market and marketing mix known as $5 P$, namely price, product, place, promotion, and people. In Indonesian the target pasar and bauran pemasaran which includes price, product, location or place, promotion, and service quality. All of these things are important and cannot be ignored by business owners because by applying the right marketing strategy will be able to influence potential customers to be able to make a purchasing decision.

Marketing is a process that consists of two processes: socially and managerially. Social defined as the role played by marketing in society. A marketer said that the role of marketing is to produce higher standards. Managerial defined as marketing process which is often described as the art of selling products, but people are surprised when they hear that the most important part of marketing is not the seller (Kotler, 2005).

In this study, the factors that influence purchasing decisions that used as variables are price, product, place, source of information (promotion), service quality (people), and internal factor, motivation. The price factor is an important variable that influences consumers in making purchasing decisions. Affordable prices are the main reference for improving marketing (Ferdinand, 2002). Price can also be an indicator of the quality of a product. If the product has good quality, the price offered will also be more expensive. The product factor is a potential weapon in increasing marketing and sales. The product with the best quality and superiority is known to be sure to survive in business competition and will certainly greatly influence consumers in making purchasing decisions.

Monroe (2005) stated that price is an economic sacrifice by the customer to obtain a product or service. In addition, price is one of the important factors for consumers to make a decision whether or not to make a transaction (Engel, Blackwell and Miniard, 1996). The price for each individual does not have to be the same it can be said to be expensive, cheap or medium; it depends on the individual's perception that is based on the environment and individual conditions (Schifman and Kanuk, 2001). According to the research of Akshay R. Rao and Kent B. Monroe (1989) in (Kumar: 2005, Dinawan: 2010), consumers have a positive relationship between price and quality of a product, and then they will compare one product to another and only then consumers make the decision to buy a product.

Kotler (2008) define product as a set of tangible and intangible attributes which include color, price, packaging, and other prestige contained in the product, which is accepted by consumers as something that can satisfy their desires. Product is anything that can be offered to the market to attract attention, use or consumption that can satisfy desires or fulfill needs.

From the background, the title of this research can be determined as "Factors Affecting Purchasing Decisions and Identification of Borax and Formalin Content in Bakso in the City of Banda Aceh".

\section{Research Purposes}

This study aimed to determine the characteristics of respondents or consumers who buy bakso in Banda Aceh and to find out the factors that influence the decision to purchase bakso in Banda Aceh. 


\section{Research Methods}

This research was conducted in businesses engaged in bakso culinary in Banda Aceh, which was determined intentionally in selecting respondents to study and compare factors owned by businesses that affect consumer purchasing power, the data used were primary data assisted with literature.

\section{Population and Samples}

The population and sample of this research were bakso culinary businessmen which were most visited by consumers.

\section{Data Analysis Method}

So that the data collected can be utilized, the data is processed and analyzed first so that later it can be used as a basis for decision making.

The method used in this study was qualitative and quantitative. Quantitative data analysis is data analysis using data in the form of figures obtained as a result of measurement or addition (Nurgiyantoro et al, 2004). To answer the purpose of this study, researcher used the Likert Scale Method and Multiple Linear Regression

To obtain quantitative data, a Likert scale was used which obtained from a list of questions classified into three levels as follows (Sugiyono, 2004), for example:
a. For answers "disagree"
$=0$
b. For answers "doubt"
$=1$
c. For answers "agree"
$=2$

The analytical tool used to examine the hypotheses that have been put forward regarding the effect of price, product, location, promotion, service, and motivation on bakso purchasing decisions in Banda Aceh was the SPSS (Statistical Package for Social Science) application program version 25.0 for Windows.

Regresi Linier Berganda, Model regresi adalah model yang digunakan untuk menganalisis pengaruh dari berbagai variabel independen terhadap satu variabel dependen (Ferdinand, 2006). Formula untuk regresi liner berganda adalah sebagai berikut:

Multiple Linear Regression is a model used to analyze the effect of various independent variables on one dependent variable (Ferdinand, 2006). The formula for multiple linear regressions is as follows:

$$
Y=a+b_{1} X_{1}+b_{2} X_{2}+b_{3} X_{3}+b_{4} X_{4}+b_{5} X_{5}+b_{6} X_{6}+e
$$

Annotations:

$$
\begin{array}{ll}
\mathrm{Y} & =\text { purchasing decision } \\
\mathrm{a} & =\text { Constanta } \\
\mathrm{X}_{1} & =\text { price } \\
\mathrm{X}_{2} & =\text { product }
\end{array}
$$




$$
\begin{array}{ll}
\mathrm{X}_{3} & =\text { place } \\
\mathrm{X}_{4} & =\text { promotion } \\
\mathrm{X}_{5} & =\text { services } \\
\mathrm{X}_{6} & =\text { motivation } \\
\mathrm{b}_{1} & =\text { regression coefficient for the price variable } \\
\mathrm{b}_{2} & =\text { regression coefficient for the product variable } \\
\mathrm{b}_{3} & =\text { regression coefficient for the place variable } \\
\mathrm{b}_{4} & =\text { regression coefficient for the promotion variable } \\
\mathrm{b}_{5} & =\text { regression coefficient for the service variable } \\
\mathrm{b}_{6} & =\text { regression coefficient for the motivation variable } \\
\mathrm{e} & =\text { error }
\end{array}
$$

\section{Results and Discussion}

Berdasarkan data dari 100 responden yang mengisi daftar pertanyaan di kuesioner, didapat kondisi responden yang mencakup jenis kelamin, usia, status pernikahan, tingkat pendidikan, pekerjaan, pendapatan, dan kota asal tempat tinggal. Pengkategorian responden dalam penelitian ini ditujukan untuk mengetahui secara pasti mengenai gambaran karakteristik responden sebagai objek dari penelitian ini. Deskripsi karakteristik konsumen yang membeli bakso di Kota Banda Aceh disajikan sebagai berikut.

Based on data from 100 respondents who filled out the questionnaire, it was obtained the data of respondents including gender, age, marital status, education level, occupation, income, and the city of residence. The categorization of respondents in this study is intended to found out exactly about the description of the characteristics of respondents as objects of this study. A description of the characteristics of consumers who buy bakso in Banda Aceh is presented as follows.

\section{Gender}

The information about gender is important to know because it deals with the influence of choices and purchasing decisions based on needs. Male consumers were as many as 16 respondents (16.0\%) and female consumers were as many as 84 respondents $(84.0 \%)$. Therefore, it can be concluded that the majority of consumers who buy bakso or visit bakso's stalls in Banda Aceh were female. This shows that women have greater culinary activities and desires than men.

Age

Age is important information. The age difference in each consumer will affect knowledge and attitudes in making purchasing decisions. In this study, it is known that 21-30 years old consumers were as many as 41 respondents (41\%), aged 31-40 years old consumers were as many as 52 respondents $(52 \%)$, and those over 40 years consumers were as many as 7 respondents (7\%). Therefore, it can be concluded that the majority of consumers who buy bakso or visit bakso's stalls in Banda Aceh were middle aged, 31-40 years old in averages. 


\section{Marital Status}

Consumers who visit bakso stalls mostly have married status, which were as many as 90 respondents (90\%). Only 10 respondents (10\%) who were single (not yet married). From the results of interviews with married consumers, it is known that they visit bakso stalls for reasons; as a way to go on a day out or recreation with family.

\section{Level of Education}

The level of formal education can affect consumer's knowledge, so that it will affect knowledge on the attributes that drive purchasing decisions. It is possible that the higher the formal education, the higher the consumer's knowledge about the attributes that influence purchasing decisions. Respondents who bought bakso at a bakso stall in Banda Aceh with SMA as the last education level were 4 respondents (4\%); 18 respondents (18\%) were graduated from Diploma 3; 64 respondents were graduated from Strata 1 (64\%); 13 respondents have postgraduate or Strata 2 level (13\%), and only 1 respondent have completed Strata 3 study (1\%). Therefore, it can be concluded that more than half of respondents who bought bakso in Banda Aceh City had a Strata 1 or undergraduate level of education. Respondents from this level of education are potential consumers in purchasing bakso.

\section{Occupations}

Occupation has a closely related with income. Personal income also has a relationship with consumers in making purchases.

Respondents who work as a private employees were 11 respondents $(11 \%)$; while there were 20 respondents who work as a civil servants (20\%); there were 13 respondents owning their own business or self-employed (13\%); housewives were the most frequent respondents, 41 respondents (41\%). Other 11 respondents $(11 \%)$ were unknown because they did not answer or leave the question unanswered. Therefore, it can be concluded that the percentage of respondents who bought the most bakso in Banda Aceh City were housewives.

\begin{tabular}{|l|c|c|}
\hline \multicolumn{1}{|c|}{ Occupations } & Frequency & Percentage (\%) \\
\hline Housewife & 41 & 41 \\
\hline Private Employee & 11 & 11 \\
\hline Students & 4 & 4 \\
\hline Civil Servants & 20 & 20 \\
\hline Entrepreneur / Self-Employed & 13 & 13 \\
\hline Others & 11 & 11 \\
\hline Total & 100 & 100 \\
\hline
\end{tabular}

\section{Income}

Respondents who bought bakso in Banda Aceh with had income less than Rp. 1.000 .000 per month were known to be 17 respondents (17\%). Respondents who had income between Rp. 1.000.000 to Rp. 3.000.000 total 35 respondents (35\%). There were 31 respondents $(31 \%)$ had income ranging from Rp. 3.000.000 to Rp. 5.000.000. Only 17 respondents (17\%) of respondents earn more than Rp 5.000.000 per month. It can be concluded that consumers who visit the bakso stall and buy bakso in Banda Aceh are dominated by respondents who have a middle class income. 


\section{Residency}

From the discussion of the characteristics of the respondents above including gender, age, marital status, education level, occupation, income, and residency, it was known that the majority of respondents who bought bakso in Banda Aceh were $84 \%$ female, aged 31 - 40 years old were $52 \%$, married were $90 \%$, have a Strata 1 education were $64 \%$, work as a housewife were $41 \%$, earn IDR 1.000 .000 - IDR 3.000 .000 per month were $35 \%$, and come from Banda Aceh were $70 \%$.

\section{Factors Affecting Consumer Purchasing Power}

Price

Consumers agree that this factor indicates that the taste of bakso they buy is in accordance with their tongue or taste. Bakso do have a delicious taste and are very interestingly served to arouse the tastes of consumers. For many people, food that is served clean and hygienic is the basis for choosing food. The majority of consumers agree that the bakso they buy are already using good quality raw materials.

\section{Service}

The portion servings of bakso that have been set properly to match consumers expectation is meant to be done to provide consumer satisfaction in eating food. Over-serving food can give boredom; on the contrary serving less-than-felt food gives less satisfaction. In this case the bakso stalls in Banda Aceh already serve the right portion so that customer satisfaction can be met. The majority of consumers also agree that bakso can replace other snacks.

In general, consumers want fast and friendly service. With quality services that are provided by stalls or restaurants, consumers will feel that their expectations are met with a fast service and friendly employee attitude. Half of consumers also agree that the restaurant manager is quite responsive to the complaints they felt.

\section{Motivation}

If observed in each condition, most consumers agree that they like bakso that easy to consume and served as a satisfying snacks. Consumers also assume that the bakso that they consume in certain stall would taste better than other; and are more famous than bakso at other stalls. Instead of self-cooking which may be inconvenient, consumers also choose to buy bakso because it can save cooking time.

Nearly half of consumers disagree that consuming bakso is a habit. But the majority agrees that they will intend to recommend the bakso they eat to others.

\section{Conclusions and Recommendations}

\section{Conclusions}

From the results of data analysis and discussion in the previous chapter, conclusions can be drawn to answer the problem formulation as follows:

1. Characteristics of consumers who make decision to purchase bakso in Banda Aceh $84 \%$ are female, 52\% are 31-40 years old, 90\% are married, 64\% are educated Strata 1, 41\% are working as a housewife , 35\% are earning IDR 1,000,000 - IDR 3,000,000 per month, and 70\% are coming from the city of Banda Aceh. 
2. Factors that influence the decision to purchase bakso in Banda Aceh are external factors, namely price, product, location, promotion, and service; and internal factors, namely motivation. Overall, those six factors are positive and together have a significant influence on purchasing decisions. However, partially, the significant effect on purchasing decisions is only three variables, namely price, service, and motivation.

\section{Recommendations}

From this research that has limitation, there are several suggestions that can be done for further research, namely:

1. Research can be carried out to focus more on one bakso stall to determine more specific consumer characteristics.

2. Hasil penelitian ini dapat disampaikan kepada pemilik usaha warung bakso agar dapat meningkatkan kualitas produk baksonya maupun meningkatkan promosi penjualannya agar lebih banyak lagi konsumen yang mengambil keputusan pembelian di warung bakso mereka masingmasing.

3. The results of this study can be conveyed to the bakso business owners in order to improve the quality of their products and increase their sales promotions so that more consumers make the purchase decision at their respective bakso stalls.

\section{References}

Mc Carthy, J, E. Perreault, and D. William, 2003. Dasar-dasar Pemasaran, Edisi kelima, Alih Bahasa: Agus Darma. Jakarta: Erlangga.

Monroe, A. C. R. Van Riel et al., 2005. Marketing Antecedent of Industrial Brand Equity: An Empirical Investigation in Specialty Chemical. Industrial Marketing Management (12) 841- 847

Sugiyono. 2004. Statistika Untuk Penelitian. Penerbit Alfabeta, Bandung

Kotler, P. 2005. Manajemen Pemasaran. Edisi XI. Jakarta: Indeks

Schiffman, L.G and L.L. Kanuk. 2007. Perilaku Konsumen, Edisi 7, Alih bahasa, Zoelkifli Kasip, Penyunting Bahasa, Rita Maharani, Penerbit PT Indeks, Jakarta.

Nurgiyantoro, Burhan, Gunawan dan Marzuki. 2004. Statistik Terapan: Untuk Penelitian Ilmu-Ilmu Sosial. Cetakan Ketiga (Revisi). Gadjah Mada University Press. Yogyakarta.

Ferdinand, A. 2006. Metode Penelitian Manajemen: Pedoman Penelitian untuk Penulisan Skripsi, Tesis, dan Disertasi Ilmu Manajemen. Semarang: Badan Penerbit Universitas Diponegoro.

\section{Copyrights}

Copyright for this article is retained by the author(s), with first publication rights granted to the journal. This is an open-access article distributed under the terms and conditions of the Creative Commons Attribution license (http://creativecommons.org/licenses/by/4.0/). 